\title{
Applications of the Comprehensive High Quality Management and its Impact in the Dimensions of the Social Responsibility: An Applied Study at the Jodanian Public and Private Hospitals
}

\author{
Dr. Suzan Saleh Darwazeh \\ Assistant Professor \\ The World Islamic Sciences \& Arts University \\ Faculty of Business Administration, Amman, Jordan
}

Kawthar Ali Shaqboua

Received: March 7, 2017 Accepted: June 7, $2017 \quad$ Published: July 1, 2017

doi:10.5296/jmr.v9i3.10890 URL: https://doi.org/10.5296/jmr.v9i3.10890

\begin{abstract}
This study aimed at recognizing applications of the comprehensive high quality management and its impact in the dimensions of the social responsibility in the Jordanian public and private hospitals, for the community of study consisted of the public and private hospitals in Amman city. Their number is amounting to (46) hospitals. And a random sample had been chosen consisted of three hospitals from every sector. The results of study showed that the level of the comprehensive high quality management, from part of significance was medium amounted to (3.492), and it was clear that the relative significance of the social responsibility was medium, amounted to (3.527). The results of study showed that there is an impact with statistical significance to the applications of the comprehensive high quality management on the dimensions of the social responsibility, where it was clear that concentration clients, commitment to the higher administration, and enabling the employees had the greatest and
\end{abstract}




\section{Macrothink}

Journal of Management Research

ISSN 1941-899X

2017, Vol. 9, No. 3

the most prominent impact in the dimensions of the social responsibility. The study deduced a number of recommendations, the most important of them are: administrations of the public and private hospitals have to confirm the policy of participating the employees in taking administrative decisions and be appreciated by the responsible, to increase the level of enabling the employees at it that is by concluding the periodical meetings to discuss the new developments of work and changes in the surrounding environment and giving them more of authorizing competences and working to morally and substantially motivating them through rewards and promotions.

Keywords: comprehensive high quality management, impact, hospital, administrations 


\section{Introduction}

The administration of the comprehensive high quality sought to assure the significance of organizations' submission of products and services enjoy a high quality serves the interest of the community in which it works and exploitation of the available resources at an efficient form.

From this point the social responsibility concept appeared in consideration of nonsatisfaction of the organization by exploiting the available resources with what serves its economic objectives, but its responsibility extends to face the societal requirements as well, for acquiring the trust of the public and the consent of customers they both assist in serving objectives of the social and economic organization and achieving the good fame to it. The health sector in Jordan is considered from the active and very important sectors in developing the individual and community through his escorting the modern developments in the domain of health care (medical \& administrative), and this requires a supporting environment to adopt the philosophy of the comprehensive high quality administration and requirements of its applications in the dimensions of the social responsibility for the hospitals, that had been an incentive for researchers to do this study on purpose of recognizing the applications of the comprehensive high quality management, from part of the high administration commitment, concentration on customers, enabling the employees and the constant improvement, and impact of these applications in the dimensions of the social responsibility from the economic, legal and the ethical sides of the social responsibility and the human dimension (Volunteering).

\section{Significance of Study}

The significance of this study comes from the significance of the research variable, the comprehensive high quality management, understanding of its data, the extent of its impact on the efficiency of organizations and their activities in improving the performance of organizations and their continuation are from the matters that form the competitive site of the organization, for which most of the organizations seek. In addition to the role of the health sector in Jordan in developing the local community through the high quality of services that should offer, and the study shares in assisting the decision- makers at hospitals to develop policies and programs concern about adopting the social responsibility towards the community of which it bears its identity, and work on promotion with it, with what serves the interest of the hospital through improving the high quality of its services.

\section{Objectives of Study}

The main objective of this study is:

Recognizing the impact of applications of the comprehensive of the high quality management in the dimensions of the social responsibility in public and private Jordanian hospitals.

Emerges from this objective many individual objectives represented in the following:

1- Reconnoitering the applications of the comprehensive high quality management in the Jordanian public and private hospitals. 
2- Reconnoitering the impact of applications of the comprehensive high quality management at the Jordanian public and private hospitals.

3- Recognizing the differences between the Jordanian public and private hospitals in adopting the social responsibility.

\section{Problem of Study}

The social responsibility is a concept that started to enlarge to cover all productive and service sectors, and though there is still a difference prevailing among organizations from part of the method of performance and policies that should be followed to adopt this concept, and because the public and private sectors are from the vital sectors with significant impact on the development of the community and work to develop it, the hospital has to seek the adoption of this trend. But because of the private hospitals seeking to glorify profits stakeholders of theirs from one part what the public hospitals suffer from fewness of available resources to do their duties from the other part, this made the adoption of the social responsibility a trend that subdues to occasions and emergent incidents on the community. This study came to shed light on the how that enable organizations (hospitals) adopt the social responsibility with its different dimensions to share in the progress of the community and its individuals

through applications of the comprehensive high quality management that establishes an organizational environment, supporting through the action of the higher administration to make available all what is needed administratively and substantially to support this trend.

\section{Questions of Study}

The questions of study were represented in the following main question:

What is the impact of hospitals (public and private) application of the comprehensive high quality management in the dimensions of the social responsibility?

\section{Theoretical Framework and Previous Studies}

\section{First: the theoretical framework}

\section{Comprehensive high quality management}

The concept of comprehensive high quality management is considered from the modern administrative concepts that aim at improving and developing the performance in a continuous form, through the response to requirements of the customer.

High quality is linguistically defined as" the good thing "depending on the lexicon of "Lisanul Arab" (Arab tongue). The origin of the word (Jawda) "high quality" is (Joud), and (Al-Jayyed=good is against Ar-Rade $=$ bad), and ( Jad Ashai that is Jawwadhu sar Jayyedan $=$ the thing became good) (Ibn Manthour, 1889, 139).

And in the Holy Quran, the Al-Mighty God says " the doing of Allah Who perfecteth all things“" ( An - Namel, verse 88), in this verse a clear pin-pointing to Allah's accuracy of everything in this world, it is a call for accuracy, perfection and doing the best at work. And 
the Al-Mighty's saying:" Lo! Allah changth not the condition of a folk until they (first) change that which is in their hearts" (Ar-Ra'd (the Thunder) verse 11). And from the Sunnah the Prophet "peace be upon him" says: (Allah love if anyone of you did a deed should be done accurately) Al-Tabarani (the Medium Lexicon, 891).

J. M. Juran and colleague defines "the high quality that it is extent of appropriateness of the product for use or unappropriate ignoring the condition of the product and its "(high quality,2014,19). But the international specification Iso 9000:2000 the high quality is Known" as the degree of fulfilling the group of genic characteristics in the product of the customer's requirements" (Al-Browari, and Bashyowat, 2010, 139).

But the American Federal Institute for High Quality defined high quality as " the correct performance of work correctly since the first time, depending on observing the evaluation of the user (the customer) in acknowledging the extent of improving the performance" (As-Samirrai, 2007, 28).

And (Taguchi, 1984) views that" high quality is avoiding loss that is caused by the product to the community after sending it to the user (the customer), that includes losses caused by failure in fulfilling the customer's expectations and failure in fulfilling the characteristics of performance and the side effects caused by the product, such as pollution, noise and else "(At-Tai, and Gadada, 2008, 29). And Deming defined it that it is "an administrative philosophy built on having the customer's consent, and achieving his needs and expectations present and future" (Deming, 1985, 1985, 56).

Through these definitions we can deduce that the high quality covers all dimensions of goods or services from part of designing, industrialization and the performance that aims mainly at fulfilling the needs and wishes of customers.

\section{Significance of the comprehensive high quality management:}

The comprehensive high quality became from the basic pivots for the success of companies in most of the world state that started deep-rooting their basic concepts, and abundant factors that led to the concern with the comprehensive high quality had collaborated, of them:

- Profit improvement and competitive ability. That is improvement in the high quality makes purchasing at the consumer acceptable with high price, in addition to increasing the size of sales.

- $\quad$ Strengthening the competitive position of the company through introducing goods or a service with high quality in accordance with the consumer's demand at a good price and a time suits the consumer.

- Decrease the average of work rotation and improvement of the performance and productivity through the moral and substantial incentives and social work, solution of work problems improvement of high quality at the group from and the team spirit 
- Increase of efficiency through loss contraction in the store- age and decrease of mistakes by the operational processes and contracting problems related with customers (Al-Kababji, and A'wwad, 2013, 377).

\section{Applications of the comprehensive high quality management}

Management of the comprehensive high quality includes abundant dimensions, that encourage companies to apply them for it covers all parts of the organization, and includes every individual inside it, and does develop regulations and procedures that support applying the management of the comprehensive high quality and its philosophy and assists to achieve the objectives of the organization and its goals, these dimensions are:

\section{First: commitment of higher administration}

From the most important principles of the comprehensive high quality management is the principle of administrative leadership, for the high quality begins from this commitment, and acquires its power and effectiveness from the higher administration of the company to create a change revolution in all activities, processes, systems, work procedures and relations with the employees with what shares in building the management of the company high quality (Olwan, 2016, 94). And the role of the higher administration in applying the management of the comprehensive high quality is represented in four principles, they are:

1. Availability of vision and imagination in the mind of the higher administration about what the organization should be on, and this imagination has to reflect the philosophy of the comprehensive high quality management.

2. The higher administration has to express its commitment for long run by applying the comprehensive high quality management.

3. Embodiment and spreading the suitable pattern of leadership for the management of comprehensive high quality.

4. Supporting the implementation process of the comprehensive high quality management at the level of the organization as a whole (At-Tai', and Gadada, 2008, 91).

\section{Second: concentration on customers}

Work is considered from the most important pivots on which the comprehensive high quality leans, the(Universal Malkom Reward )had given 25\% of its grades for the concern of the organization with its customers and achieving their wishes, and term "customer" had covered the comprehensive high quality both the internal and external customers(Hammoud,2009,98). We deduce that the significance of concentration on the customers comes from their being the best who determine or evaluate the high quality of the product (goods and services ) through the value and the characteristics that assist on satisfying their needs, and achieve their loyalty to the organization, and also submitting everything new to acquire new customers by introducing what wish of specifications in the products.

\section{Third: empowerment of employees}

The effective management in the comprehensive high quality is that which creates the great concern amongst employees in their works and occupations, where they feel as if they 
possess the organization in which they work, and this is what some people call it "the psychological possession", where the employee feels that he owns the company so his success is its, and his failure is its (AL- Khalayla, 2012, 49). What is meant by the effective management, is that process through which individuals are allowed to participation in planning and controlling the tasks of their occupations to achieve the individual and organizational objectives through the exchange of information and participation in decisions making (Al_Shabab, and Abu Hammour, 2012, 221). And emerging employees can be achieved through depending the moral and substantial motivation and empowering them of their deeds either through confirming the difference of work to accomplish tasks, or through what is called circles of high quality, that represent groups of individuals having cognitions, skills, and appropriate experiences collect together to treat and solve problems connected with high quality to treat and solve problems connected with high quality(Al- Kababji, and Abu Oudeh,2014,376). Both researchers summarize the previous ideas that empowerment is a new organization strategy aims at authorizing the employees a part of authority and granting them the freedom of taking routine decisions related with the performance of work, and bearing the responsibility of those decisions aiming at fulfilling needs of customers, and achieving the objectives and goals of the organization.

\section{Fourth: continuous improvement}

"Continuous improvement was defined that it had been a comprehensive process includes all activities of the organization either inputs, transformation processes, or outputs till transference of products to the customer, and it may result from the continuous process of improvement decrease in the inputs, or increase of outputs or improvement the high quality of outputs or rise of the employees consent level or the customers consent" (Zeidan, 2009, 242).

The comprehensive high quality management depends on the continuous efforts of improvement and development, starting from the principle of development opportunities, and improvement do not terminate at all how come was the efficiency of performance and its effectiveness amounted, and the level of high quality and wishes of users and their expectations are not constant, but changeable. Therefore, the elements of the organization should be evaluated constantly, and work on laying programs to improve them constantly to agree with customers' tastes and their wishes, present and future expectations (Al-Kbeisi,2011.15). These four dimensions had been chosen (commitment of the higher administration, concentration on customers, empowerment of the employees and continuous improvement) as an independent variable to achieve this study.

\section{Social responsibility}

\section{What is the social responsibility?}

At the advent of the second half of the Twentieth Century many researchers concentrated on the necessity for the private business organizations to avoid concern with profits, as a goal attempt to glorify at different conditions and circumstances. Darker had defined the social responsibility as "the commitment of business organization towards the community in which it works, and this commitment becomes larger by the largeness of interest owners categories in this community and the variation of their trends (Mansour and Al Khafji, 2008, 288). 
And it was known as a process of achieving balance a many numerous parties, have joint or intersecting interests, they are the partners or share _ owners the local surrounding community and consumers of services or the company products and the group of employees in the company. The social responsibility emerges in this side from the business organizations non-doing or implementing their duties toward the community (Jaradatand Abul Hamam, 2011, 29). But (Holmes ) had said the social responsibility is nothing, but a commitment of business organizations toward the community in which they work, that is by sharing with a big group of social activities, such as fighting poverty, improving service, struggling against pollution, decreasing unemployment and solving the problem of housing and transportations (Al Hawamdeh,2013,84). By what had preceded we can recognize that the social responsibility is a social and ethical volunteering commitment from the organization, towards interest owners who affect and are affected by them. In addition to its roles in achieving the economic profits, and glorifying profits, for it is required to participate in all activities and social efficacies that work to the development and welfare of the community as a whole.

\section{Significance of the social responsibility}

With the increase of concern about the social responsibility of organization, there became insisting needs to increase the role of associations in beating the social responsibility, that works to let organizations succeed and serve the community as a whole, and share in developing it. And the social responsibility is considered a competitive trait for the organization in the shadow of markets, with serious competition, for this responsibility with the element of work in the organization from part of employees perception for this age, with what guarantees their effective sharing in implementing the required tasks. (Al Omari, and zargoon, 2014, 204).

\section{Dimensions of social responsibility:}

(Carroll's) study (1991) is considered one of the most important studies that discussed the social responsibility through four specified dimensions made it clear at a hierarchy form. It is (Al Ghalibi, and Al Ameri, 2005, 85).

Volunteering human responsibility: behaving as good citizen shares in reinforcing resources in the community and improving the type of life in it.

Ethically responsibility: when the organization observes in its decisions the ethics, it does the correct thing, right, and avoldshurting the differ rent categories. 
The legal responsibility: through obedience to laws, because laws are the mirror that reflects what is right or wrong in the community: represents the basic rule of work.

Economic responsibility: being the organization achieves a profit, this represents a basic rule of fulfilling the requirements.

Figure 1. (Carroll Pyramid) Social Responsibility

Reference: At Ghalibi and At Ameri, the social Responsibility and Business morals, 2015, P.85.

The social responsibility according to (Carroll), is the result of the four types total of the responsibility, that can be written in the following formula:

The social responsibility $=$ the economic responsibility, the legal responsibility, the ethical responsibility, and the human volunteering responsibility.

Economic dimension: indicates to businesses sector: it has to be productive and profitable, and fulfill the consuming needs of the community. It also leans on the competitive principles and technological development, where it covers a big group of the social responsibility elements that should be taken in the track of respecting the rules of the free and just competition and complete benefitting from the technological development, with what does not catch damage with the community and the environment.

Legal dimension: any organization at practicing its activities and different functions should be agreed with the system of laws and legislation, that guarantee the rights of protecting the environment, professional safety, and laws of protecting the consumer and justice at a form shares in stabilizing the relationship with the consumer and employees of all sexes, ethnics, religions and protecting them from forgery and cheating, and also limiting the violent use of natural resources and preventing pollution, assisting individuals in cases of injury and saving work for the woman and handicapped people .

Ethical dimension: indicates to a group of activities and banned practices by the community and non provided in the law and embody standards and rules, that reflect desire on consumers, employees, shareholders, and the community at just form, together with respect and protecting the moral rights for interest owners. These responsibilities require from the companies to do what is right and just without seeking the legal framework.

Volunteering human dimension: 
The human responsibility for the work sector is considered an optional responsibility and it is difficult to judge it and make sure of it. This dimension forms the traits that the community wishes to obtain it from the association, such as support offered to projects and charitable activities aim at preserving the type of life. And this serial is considered in the adoption of the social responsibility of a real case, for it came to clear the connection among these dimensions, also it cannot be expected from the business organizations human initiative and responsibility if these organizations had never crossed a long track in the frame work of bearing their economic, legal and ethical responsibility towards societies that they serve.

\section{Second: previous studies}

Arabic studies:

1. An_Nashmi, Qaid study (2015) entitled:"The Relationship between the social responsibility and the Mental from of the Organization:"A Case study at the University of Science and Technology in Yemen". This study aimed at uncovering the relationship between the social responsibility and the mental form of the University of Science and Technology in Yemen from the point of view of a sample of students. And the study aimed at analyzing the commitment of the university with the social responsibility towards (the community, environment, students and employees) and the mental form of the university of science and Technology in Yemen, that is the university commitment with dimensions of the social responsibility of the university at the community, environment students, and the employees. And the study had recommended to increase the impact of universities role in the domain of social responsibility, because it is a part of the national responsibility of the universities.

2. Azubi study (2015) entitled "extent of Impact of the private Jordanian hospitals administrations on applying requirements of comprehensive quality management and its reflections on quality of information at them". This study aimed at recognizing the extent of applying principles of comprehensive quality management and its relationship with improving the level of information quality at private Jordanian hospitals. Results of study indicated that level of applying principles of comprehensive quality management came at a high degree, and also cleared that there is a positive connective relationship between applying principles of comprehensive quality in addition to existence of differences with statistical significance between the organizational characteristics of hospitals, and the level of applying principles of comprehensive quality management. And the study included a number of recommendations, from the most important of which was reinforcement and stabilization of satisfaction at the higher administration and the employees with the significance of applying the comprehensive quality management.

3. An_Neimi study (2015) entitled:"the social Responsibility and its effect in the capital in the industrial companies enlisted in Amman stock market. The study had deduced the existence of negative relationship between the size of the total expenditure and expressing the social responsibility and cost of the capital, and the relationship of each of these variables had been examined alone, where existence of negative relationship, as well, between the cost of the capital and all the independent variables, but there is no impact with statistical significance of the expenditure on the community and environment, the matter that is 
ascribed to the fewness of the expended amounts on them both. And the study had proposed a group of recommendations, the most important of them is the necessity of the Jordanian companies concern with their social responsibility through finding internal divisions concerning the social responsibility.

\section{Foreign studies}

1. Asknyomi study (2012) entitled:"'( Survey of corporate social responsibility practices in Nigerian Manufacturing sector): A field study". This study discussed the concept of the social responsibility, and aimed at illustrating that the organization that has high investments has positive relations with the social responsibility in accordance with the theory of interest owners, and the research was designed through doing survey and study on(15) industrial organizations, were randomly chosen in the sector of foods and drinks. Results of analyzing data had disclosed that the social responsibility of organizations is a familiar concept in the sector of Nigerian organizations, but most of organizations do not regularly share in activities of the social responsibility, and not also in any domains of the social responsibility activities and developing youth, sports and woman support. The study deduced numerous results, the most important of which is submitting evidence that investments of industrial organizations in the social responsibility do not scarcely be mentioned, and it is possible for business organizations to work successfully without cooperation with the community and concern with the social responsibility for individuals of the community in the external environment.

2. Tuan study (2012) entitled:"Corporate social Responsibility, Health Service Quality and Brand Equity “. This study aimed at reconnoitering if the activities of the public clinics led by the social responsibility, and if they affect the care quality of patients, that in turn affects the trade mark of hospitals which have been built through the quality health care services by examining the hypotheses on the relations between the present and previous trade mark. (417) questionnaires were filled and were appropriate for analysis related with (835) employees. Examining data and analyzing them, there was a strong indicator to the effectiveness of public clinics, that grant a high concern with the services quality offered to the patients and their care between the trade mark of the hospital.

3. (Kober, et. al, 2012) study entitled:'Impact of the comprehensive quality management adoption on small and Medium Enterprises Financial performance". This study aimed at recognizing the Impact of adopting the comprehensive quality management on small and medium projects financial performance, where one of the administrative counting practices was examined, represented in the comprehensive quality and its impact on improving the financial performance of the companies with small and medium size. And the surveying analysis of the Australian companies, which their number amounted to (3776) companies had been used. Their financial data were obtained from the Australian statistical Center. Results had shown that there is no impact of using adoption of the comprehensive quality management system on improving the financial performance of the small and medium companies after controlling the variable of size and risk.

\section{Hypotheses of study}




\section{I Macrothink}

The first main hypothesis: there is no impact with statistical significance at the level of morale $(p<0.05)$ for applications of the comprehensive quality management altogether in the dimensions of the social responsibility. And branches from it the following subsidiary hypotheses:

_The first: there is no impact with statistical significance at the level of morale $(\mathrm{P}<0.05)$ for the commitment of the higher administration in the dimensions of the social responsibility.

_The second: there is no impact with statistical significance at the level of morale $(\mathrm{P}<0.05)$ to concentrate on clients in the dimensions of the social responsibility.

_ The third: there is no impact with statistical significance at the level of morale $(\mathrm{P}<0.05)$ to enable employees in the dimensions of the social responsibility.

_The fourth: there is no impact with statistical significance at the level of morale $(\mathrm{P}<0.05)$ for the continuous improvement in the dimensions of the social responsibility.

The second main hypothesis: there are no differences with statistical significance at the level of morale $(\mathrm{P}<0.05)$ among responses of the examinees in adopting the social responsibility a scribed to the demographic variables, branches from it the following subsidiary hypotheses:

The first: there are no differences with statistical significance at the level of morale $(\mathrm{P}<0.05)$ among responses of examinees in adopting the social responsibility a scribed to the social type.

The second: there is no differences with statistical significance at the level of morale $(\mathrm{P}<0.05)$ among responses of the examinees in adopting the social responsibility ascribed to the age.

The third: there are no differences with statistical significance at the level of morale $(\mathrm{P}<0.05)$ among responses of examinees in adopting the social responsibility ascribed to the scientific qualification.

The fourth: there is no differences with statistical significance at the level of morale $(\mathrm{P}<0.05)$ among responses of the examinees in adopting the social responsibility ascribed to the national nomination.

The third main hypothesis: there are no differences with statistical significance at the level of morale $(\mathrm{P}<0.05)$ among the public and private hospitals in adopting the social responsibility.

Methodology of Study: this study is considered descriptive and analytical one, aims at answering a primary inquiry relates with the impact of the hospitals' (public and private) applying the comprehensive quality management in the dimensions of social responsibility, that is, depending on two types of data; they both are the secondary data, that is through revising literatures, magazines, courses and previous studies about the subject of study and the initial data through developing a questionnaire to collect the data of study. 


\section{Macrothink}

Community of Study: the community of study consisted of private and public hospitals (whose number amounted to (46) hospitals).

The Sample of Study: both researchers depended the appropriate class random sample technique to draw the sample from the examined hospitals. Six hospitals had been chosen, three from the public health sector, they are: Al-Basheer Hospital, Al-Totonji hospital, Prince Hussein Bin Abdullah the 2nd Hospital, and three the hospitals represent the private sector, they are Jordan Hospital, the Islamic Hospital and Al-Khaldi Hospital. The number of examinees (analysis unit) in hospitals of the public sector, the examinees hospitals amounted to (207) individuals, meanwhile the number of examinees at hospitals of the private sector amounted to (186) individuals. So the analysis unit consisted of (393) individuals. Depending on Sekaran's statistical tables (2003) to specify the size of the sample (220) questionnaires were distributed, and (208) questionnaires were returned and all of them were pliable to statistical analysis, and at a rate of retrieval amounted to $(\% 94.5)$ of the distributed questionnaires. Demographic characteristics of the sample of study came as in Table (1) that illustrates the demographic variables of the sample of study individuals from part of the social type age, scientific qualification, the occupational nomination, and type of the hospital. 


\section{MInstitute Macrothink $_{\text {Intion }}$}

Table 1.

\begin{tabular}{|c|c|c|c|c|}
\hline No. & Variable & Class & Repetition & Percentage \\
\hline 1 & Social Type & Male & 103 & 49.5 \\
& & Female & 105 & 50.5 \\
& & Total & 100 & $\% 100$ \\
\hline 2 & \multirow{2}{*}{ Age } & Below 35years & 83 & 39.5 \\
& & 35 to below 45 & 74 & 35.6 \\
& & T5 less than 55 55years and a bore & 37 & 17.8 \\
& & Total & 14 & 6.7 \\
& & & 100 & $\% 100$ \\
\hline 3 & Scientific & Diploma & 45 & 21.5 \\
& & Bachelor & 125 & 60.1 \\
& & Master & 21 & 10.1 \\
& \multirow{2}{*}{ Qualification } & Doctorate & 17 & 8.2 \\
& & Total & 8 & 3.8 \\
\hline 4 & \multirow{2}{*}{ Occupational } & Manager & 11 & 5.3 \\
& \multirow{2}{*}{ Nomination } & Chair & 75 & 36.1 \\
& & merson supervisor & 114 & 54.8 \\
\hline 5 & Hospital & & 110 & 52.9 \\
& & Public & 98 & 47.1 \\
& & Private & 208 & $\% 100$ \\
\hline
\end{tabular}

Table(1) illustrates that the rate of males less than the rate of females, that refers to mutual approach of both sexes from part of adopting the administrative tasks, and that is ascribed to fair appointments in the concerned hospitals from part of populating the observation unit we notice that the class of population (less than 35 is the biggest class) and this is an evidence on the hospitals concentration on the class of young people to adopt the administrative tasks, from part of the scientific qualification, it was Pin-pointed that persons bearing the bachelor degree formed the greatest class and it is the lowest limit required for appointment at hospitals, also the opportunity of these people is the strongest for occupation development, but existence of accepted rate from the bearers of post-graduate studies, it is an evidence on managers owing Knowledge that qualifies them to do their tasks, due to the occupational nomination. It was cleared that the class of manager formed the least class mean while the supervisor class the greater rate. This agrees with the administrative hierarchy, where the number increases the more we aim at the basement of the pyramid. But due to the number of the employees at public hospitals it was pin-pointed that the employees (observation unit) are more than the private hospitals and this shows the accessibility of recovery from the public hospitals, which were more cooperative.

\section{Instrument of Study}

Both researchers did prepare the questionnaire, that consisted of three parts, for the first part included the demographic variables, the second part included the independent variable "the 
comprehensive quality management, and the third part included the subordinate variable" adopting the social responsibility", that is aiming at collecting the initial data from the employees at the public and private hospitals.

\section{Validity and Reliability of the Study Instrument}

\section{First: Superficial Validity}

To make sure of the superficial validity of the scale assistance had been done with an elite selected from the arbitrators with experience and specialization in the academic domain, their notes and proposals about the questionnaire had been taken, from part of efficiency of the study instrument, its clarity, connection, coherence and the extent of questions concordance with the hoped variables.

\section{Second: test of the instrument of study reliability}

To measure the reliability of instrument both researchers did test the extent of internal consistency for items of the scale, where the evaluation of scale consistency was done by Cronbach's Alpha Coefficient and coefficients of reliability indicated to the instrument in general enjoyment with high reliability coefficient on the ability of instrument to achieve purposes of study in accordance with (Sekaran, 2003) as shown in the Table (2).

Table 2. Values of internal consistency coefficient for the instrument of study

\begin{tabular}{|l|l|l|l|l|l|}
\hline & Dimension & $\begin{array}{l}\text { Alpha } \\
\text { value }\end{array}$ & & dimension & $\begin{array}{l}\text { Alpha } \\
\text { value }\end{array}$ \\
\hline \multirow{4}{*}{$\begin{array}{l}\text { Quality } \\
\text { Management }\end{array}$} & $\begin{array}{l}\text { Higher } \\
\text { Administration } \\
\text { commitment }\end{array}$ & 0.881 & & $\begin{array}{l}\text { Economic } \\
\text { dimension }\end{array}$ & 0.784 \\
\cline { 2 - 3 } & $\begin{array}{l}\text { Concentration } \\
\text { on clients }\end{array}$ & 0.896 & \multirow{2}{*}{$\begin{array}{l}\text { Social } \\
\text { responsibility }\end{array}$} & $\begin{array}{l}\text { Legal } \\
\text { dimension }\end{array}$ & 0.799 \\
\cline { 2 - 3 } & $\begin{array}{l}\text { Employees } \\
\text { Empowerment }\end{array}$ & 0.896 & & $\begin{array}{l}\text { Ethical } \\
\text { dimension }\end{array}$ & 0.833 \\
\cline { 2 - 3 } & $\begin{array}{l}\text { Continuous } \\
\text { Improvement }\end{array}$ & 0.887 & & $\begin{array}{l}\text { Human } \\
\text { dimension }\end{array}$ & 0.921 \\
\cline { 2 - 3 } & All Dimensions & 0.958 & & $\begin{array}{l}\text { Social } \\
\text { dimension }\end{array}$ & 0.936 \\
& & & & & \\
\hline
\end{tabular}

\section{Statistical processes}

Both researchers used the following statistical techniques:

He statistical package for social sciences_SPSS in the following statistical analyses:

1. Descriptive statistical: repetitions, percentages, arithmetic means and standard deviations had been used to submit a comprehensive description to the degree of the sample of study individuals agreement on the different items. 
2. Procedures of the descriptive statistics, through the percentages, repetitions, arithmetic means and standard deviations.

3. Internal consistency coefficient (Cronbach Alpha to measure the reliability of study instrument, it is the questionnaire.

4. Test of the multiple linear connection problem.

5. Simple and Multiple linear regression analysis

6. Independent sample t-test of the One way ANOVA analysis.

7. The relative significance had been specified in accordance with the following formation and in accordance with the fivefold scale of answer replacements of each item, for the levels number are: low, medium, and high, and so it is:

8. The low level is _ 1 _ less than 2.33 the medium level is _ 2.33_ less than 3.66 the high level is ${ }_{-} 3.66_{-} 5.00$

\section{Show of study results and discussion}

In this part of study we show the test of hypotheses, for submission of the first main hypotheses branching from them to analyze the simple multiple linear Regression, Mean while the second hypothesis was tested by using independent sample t_test and analyzing the one way _ ANOVA, but the third hypothesis was tested by using the independent sample $t_{-}$ test. The results by using the independent sample $t_{-}$test. The results had been as follows:

The first main hypothesis: "there is no impact with statistical significance at the morale level $(\mathrm{P}<0.05)$ for the comprehensive quality management applications in dimensions of social responsibility".

To test the first main hypothesis the Multiple Regression analysis was used, and the results were as follows: 


\section{Macrothink}

Table 3. Results of testing the impact of the comprehensive quality

\begin{tabular}{|c|c|c|c|c|c|c|c|c|c|c|}
\hline \multirow[t]{2}{*}{$\begin{array}{l}\text { Subord-inate } \\
\text { Variable }\end{array}$} & \multicolumn{2}{|c|}{ Model Summary } & \multicolumn{3}{|c|}{$\begin{array}{c}\text { management applications } \\
\text { altogether on the social } \\
\text { responsibility ANOVA } \\
\text { Analysis }\end{array}$} & \multicolumn{5}{|c|}{ Coefficient Table } \\
\hline & \begin{tabular}{l}
\multicolumn{1}{c}{$\mathrm{R}$} \\
Connectio \\
$\mathrm{n}$ \\
coefficient
\end{tabular} & $\begin{array}{l}\quad \mathrm{R} \\
\text { Specificatio } \\
\mathrm{n} \\
\text { coefficient }\end{array}$ & Sig F & $\begin{array}{c}\text { Freedom } \\
\text { Degree }\end{array}$ & $\begin{array}{c}\text { Counted } \\
\text { F }\end{array}$ & & B & $\begin{array}{c}\text { Standard } \\
\text { Error }\end{array}$ & $\mathrm{T}$ & Sigt \\
\hline \multirow{4}{*}{$\begin{array}{c}\text { Social } \\
\text { Respon-sibilit } \\
\mathrm{y}\end{array}$} & \multirow[t]{4}{*}{0.807} & \multirow[t]{4}{*}{0.652} & \multirow[t]{4}{*}{94.953} & \multirow[t]{4}{*}{4} & \multirow[t]{4}{*}{0.000} & $\begin{array}{c}\text { Higher } \\
\text { Administration } \\
\text { commitment }\end{array}$ & 0.118 & 0.073 & 1.697 & 0.110 \\
\hline & & & & & & $\begin{array}{c}\text { Concentration } \\
\text { on clients }\end{array}$ & 0.342 & 0.060 & 5.720 & 0.000 \\
\hline & & & & & & $\begin{array}{l}\text { Employees } \\
\text { Empowerment }\end{array}$ & 0.248 & 0.058 & 4.260 & 0.000 \\
\hline & & & & & & $\begin{array}{l}\text { Continuous } \\
\text { Improvement }\end{array}$ & 0.038 & 0.069 & 0.548 & 0.585 \\
\hline
\end{tabular}

*The impact is with statistical significance at the level $(\mathrm{P}<0.05)$

Results of the table(3) indicate that connection coefficient $(\mathrm{R}=0.807)$ indicates to the relationship between the independent variables and subordinate variable, also the impact of the independent variables (applications of the comprehensive quality management) on the subordinate (the social responsibility) is an impact with statistical significance, were the counted F.value is $(94.953)$, and at a level significance ( $\mathrm{sig}=0.000)$ it is less than 0.05 , for the value of specification coefficient (R0.652) and it indicates to (\%65.2) of variation in (the social responsibility) it can be explained through Variation in (applications of the comprehensive quality management) altogether.

But the table of coefficients had shown that $\mathrm{B}$ value at (the higher administration commitment) had amounted (0.118) and that the value of $t$ at(1.607), and at a morale level (Sig=0.110), that indicates to impact of this moral variable, Also B was at (employees empowerment) with a value amounted (0.248) and the value of $t$ was(4.260), and at a moral level of ( $\mathrm{Sig}=0.000)$, that indicates that the impact of this dimension is moral. But the value of $\mathrm{B}$ at (the continuous improvement) had amounted (0.038) and the value of $\mathrm{t}$ at it is $(0.548)$, and with a moral level ( $\mathrm{sig}=0.585)$, that indicates that the impact of this variable is not moral. This means that all applications have an impact, but the cause of this impact is the concentration and empowering the employees. And due to what preceded, we reject the first main hypothesis and accept the replacing hypothesis that words: 


\section{Ml Macrothink}

"There is an impact with statistical significance at a morale level $(\mathrm{P}<0.05)$ of applications of the comprehensive quality management in the dimensions of the social responsibility" and that is ascribed to that the hospital to be able to adopt the social responsibility and should possess an organizational administrative framework to be able to confront the variables in the surrounding environment and has an ability to adapt with those variables, this does not be valid except through applying the comprehensive quality management and understanding its data.

The subsidiary hypotheses from the first main hypothesis for analyzing the simple linear regression had been subdued, they were as follows:

1. Hol: "there is no impact with statistical significance at a moral level (P 0.05) for the higher administration to adopt the social responsibility".

Table 4. Results of impact test (the higher administration commitment) on the Social responsibility

\begin{tabular}{|c|c|c|c|c|c|c|c|c|c|c|}
\hline \multirow{2}{*}{$\begin{array}{c}\text { Subord-inate } \\
\text { Variable }\end{array}$} & \multicolumn{2}{|c|}{$\begin{array}{c}\text { Model } \\
\text { Summary }\end{array}$} & \multicolumn{3}{|c|}{$\begin{array}{l}\text { ANOVA } \\
\text { Analysis }\end{array}$} & \multicolumn{5}{|c|}{ Coefficient Table } \\
\hline & $\begin{array}{c}\mathrm{R} \\
\text { Connect } \\
\text {-ion } \\
\text { Coeffic } \\
\text {-ient }\end{array}$ & $\begin{array}{c}\mathrm{R} \\
\text { Specify-in } \\
\mathrm{g} \\
\text { Coeffici-e } \\
\mathrm{nt}\end{array}$ & $\begin{array}{c}\text { Counted } \\
\text { F }\end{array}$ & $\begin{array}{c}\text { Degree } \\
\text { Of } \\
\text { Freedom }\end{array}$ & $\begin{array}{l}\text { Sig F* } \\
\text { Level }\end{array}$ & Statement & B & $\begin{array}{l}\text { Stand-a } \\
\quad \text { rd } \\
\text { Error }\end{array}$ & $\begin{array}{c}\text { Counted } \\
\mathrm{T}\end{array}$ & $\begin{array}{c}\text { Sig } t^{*} \\
\text { Significa-nc } \\
\text { e } \\
\text { Level }\end{array}$ \\
\hline $\begin{array}{l}\text { Social Res- } \\
\text { ponsibility }\end{array}$ & 0.707 & 0.500 & $\begin{array}{c}205.73 \\
7\end{array}$ & 1 & $\begin{array}{c}0.00 \\
0\end{array}$ & $\begin{array}{l}\text { H.Administ-rati } \\
\text { on } \\
\text { Commitment }\end{array}$ & $\begin{array}{c}0.65 \\
0\end{array}$ & 0.045 & $\begin{array}{c}14.34 \\
4\end{array}$ & $\begin{array}{c}0.00 \\
0\end{array}$ \\
\hline
\end{tabular}

*Impact be with statistical significance of at the level $(\mathrm{P}<0.05)$

Results of Table4 indicate that the value is $(r=0.707)$, this means that there is a positive relationship between (the higher administration commitment) and (the social responsibility). It is cleared that the value of specifying coefficient is $(\mathrm{r}=0.500)$, and this means that (the higher administration commitment) may explain the sum of (\%50.0) from variation in (the social responsibility), while the other remaining factors stable.

It is also cleared that $(\mathrm{F})$ value had amounted (205.737) at trust level ( $\mathrm{Sig}=0.000)$. This assures the moral regression at level $(\mathrm{P}<0.05)$ and at only one degree of freedom.

It is also clear from the coefficients table that the value of $(B=0.650)$ and the value of $(\mathrm{r}=14.344)$ at the level of trust $(\mathrm{Sig}=0.000)$ and this assures the morale of regression at the level $(\mathrm{P}<0.05)$. 
And due to what preceded, we reject the first subsidiary nihilist hypothesis and accept the replacing subsidiary hypothesis that words:

"There is an impact with statistical significance at morale level $(\mathrm{P}<0.05)$ for the commitment of the higher administration in dimensions of the social responsibility" and that is ascribed that the higher administration is the head of administrative pyramid and it is that lays policies and strategies concerning work performance.

2-Hol: "there is no impact with statistical significance at a morale level $(\mathrm{P}, 0.05)$ to concentrate on the clients in dimensions of the social responsibility:

Table 5. Results of testing the impact of (concentrating on the clients) on the social responsibility

\begin{tabular}{|c|c|c|c|c|c|c|c|c|c|c|}
\hline \multirow{2}{*}{$\begin{array}{c}\text { Subord } \\
\text {-inate } \\
\text { Variable }\end{array}$} & \multicolumn{2}{|c|}{$\begin{array}{c}\text { Model } \\
\text { Summary }\end{array}$} & \multicolumn{3}{|c|}{$\begin{array}{l}\text { ANOVA } \\
\text { Analysis }\end{array}$} & \multicolumn{5}{|c|}{ Coefficients Table } \\
\hline & $\begin{array}{c}\mathrm{R} \\
\text { Connection } \\
\text { Coeffic-ient }\end{array}$ & $\begin{array}{c}\mathrm{R} \\
\text { Specify-in } \\
\mathrm{g} \\
\text { Coeffic-ie } \\
\mathrm{nt}\end{array}$ & $\begin{array}{c}\text { Counted } \\
\text { F }\end{array}$ & $\begin{array}{c}\text { Degree } \\
\text { Of } \\
\text { Freedom } \\
\text { GF }\end{array}$ & $\begin{array}{l}\text { Sig F* } \\
\text { Statist. } \\
\text { Signif. }\end{array}$ & Statement & B & $\begin{array}{l}\text { Stand-a } \\
\text { rd } \\
\text { Error }\end{array}$ & $\begin{array}{c}\text { Counted } \\
\mathrm{T}\end{array}$ & $\begin{array}{c}\text { Sig E } \\
\text { Statist-ic } \\
\quad \text { al } \\
\text { Signif }\end{array}$ \\
\hline $\begin{array}{c}\text { Social } \\
\text { Responsib } \\
\text {-ility }\end{array}$ & 0.758 & 0.574 & $\begin{array}{c}277.97 \\
5\end{array}$ & 1 & 0.00 & $\begin{array}{l}\text { Concentra-tio } \\
\text { n on } \\
\text { clients }\end{array}$ & $\begin{array}{c}0.63 \\
3\end{array}$ & 0.038 & $\begin{array}{c}16.66 \\
7\end{array}$ & $\begin{array}{c}0.00 \\
0\end{array}$ \\
\hline
\end{tabular}

*The impact is with Statistical Significance at the level $(\mathrm{P}<0.05)$.

Results of the Table(5) indicate that the value( $\mathrm{r}=0.758)$, and this means that there is a positive relationship between (concentration on clients) and (the social responsibility). And pin-points that the value of specifying coefficient $(\mathrm{r}=0.574)$, and this means that (concentrates on clients) had explained the sum of $(\% 57.4)$ from variation in the (social responsibility), with remaining other factors stable. Also clears that the value of (F) had amounted (277.795) at the level of trust $(\mathrm{Sig}=0.000)$ this assures the moral of regression at the level $(\mathrm{P}<0.05)$ and at only one degree of freedom.

Also it is clear from the table of coefficients that the value $(\mathrm{B}=0.633)$ and the value $(\mathrm{t}=16.667)$ at the level of trust $(\mathrm{Sig}=0.000)$ and this assures the morale coefficient at the level $(\mathrm{P}<0.05)$.

And due to what preceded, we reject the second subsidiary nihilist hypothesis and accept the replacing subsidiary hypothesis that words:

"There is an impact with statistical significance at the morale level $(\mathrm{P}<0.05)$ to concentrate on the client in dimensions of the Social Responsibility" that is ascribed to that users are a part of the community to which the hospital seeks to serve, and so it works to increase the number 
of dealers with the hospital, and that results in acquiring their satisfaction and offering the best service and so preserving the fame of the hospital, here the comprehensive quality management intersects with the social responsibility in serving and fulfilling the needs of users.

3- Hol: "There is no impact with statistical significance at the morale level $(\mathrm{P}<0.05)$ to empower employees in dimensions of the social responsibility".

Table 6. Results of testing the impact of (empowering employees) on the Social Responsibility

\begin{tabular}{|c|c|c|c|c|c|c|c|c|c|c|}
\hline \multirow{2}{*}{$\begin{array}{l}\text { Subordin- } \\
\text { ate } \\
\text { Variable }\end{array}$} & \multicolumn{2}{|c|}{$\begin{array}{c}\text { Model } \\
\text { Summary }\end{array}$} & \multicolumn{3}{|c|}{ ANOVa Analysis } & \multicolumn{5}{|c|}{ Coefficients Table } \\
\hline & $\begin{array}{c}\mathrm{R} \\
\text { Connection } \\
\text { Coefficient }\end{array}$ & $\begin{array}{c}\mathrm{R} \\
\text { Specifying } \\
\text { Coefficient }\end{array}$ & $\begin{array}{l}\text { Counted } \\
\qquad \mathrm{F}\end{array}$ & $\begin{array}{c}\text { Degree } \\
\text { Of } \\
\text { Freedom } \\
\text { of }\end{array}$ & $\begin{array}{c}\text { Sig F* } \\
\text { Statistical } \\
\text { Significance }\end{array}$ & Statement & B & $\begin{array}{c}\text { Standard } \\
\text { Error }\end{array}$ & $\begin{array}{c}\text { Counted } \\
\text { T }\end{array}$ & $\begin{array}{c}\text { Sig } 1^{*} \\
\text { Statistical } \\
\text { Significanc } \\
\text { e }\end{array}$ \\
\hline $\begin{array}{c}\text { Social } \\
\text { Responsi-bi } \\
\text { lity }\end{array}$ & 0721 & 0.520 & 223.52 & 1 & 0.00 & $\begin{array}{l}\text { Employee } \\
\text { s } \\
\text { Empower } \\
\text { ment }\end{array}$ & $\begin{array}{c}0.58 \\
8\end{array}$ & 0.039 & 14.952 & 0.000 \\
\hline
\end{tabular}

*The impact be with Statistical Significance at the level $(\mathrm{P} \geq 0.05)$

Results of Table (6) indicates that the value $(r=0.721)$, this means that there is a positive relationship between (employees empowerment) and (the social responsibility). It is clear that the value of specifying coefficient $(r=0.520)$, this means that (employee empowerment) had explained the sum of (\%52.0) from variation in (the social responsibility), remaining the other factors stable. It is also clear that $F$ value had amounted (223.523) at the level of trust ( $\mathrm{sig}=$ $0.000)$ this assures the morale regression at the level $(\mathrm{P} \geq 0.05)$ and at one degree of freedom.

"There is an impact with statistical significance at the morale significance $(\mathrm{P} \geq 0.05)$ to empower employees in the dimensions of social responsibility" ascribed that the employees are part of the community to which the hospital seeks to serve, and concern about, giving them their substantial and morale rights, and all of them are enlisted within the responsibility of the hospital management towards them. Here the comprehensive quality management intersects with the social responsibility in serving and fulfilling the needs of this sector, that forms a part of the local community.

4-Hol: "there is no impact with statistical significance at the morale level $(\mathrm{P} \geq 0.05)$ t0 the continuous improvement in dimensions of the social responsibility". 


\section{Macrothink}

Journal of Management Research

ISSN 1941-899X

2017, Vol. 9, No. 3

Table 7. Results of testing the impact of (continuous improvement on the social responsibility

\begin{tabular}{|c|c|c|c|c|c|c|c|c|c|c|}
\hline \multirow{2}{*}{$\begin{array}{c}\text { Subordi-nate } \\
\text { Variable }\end{array}$} & \multicolumn{2}{|c|}{ Model Summary } & \multicolumn{3}{|c|}{ ANOVA Analysis } & \multicolumn{5}{|c|}{ Coefficient Table } \\
\hline & $\begin{array}{c}\mathrm{R} \\
\text { Connec-tion } \\
\text { Coeffici-ent }\end{array}$ & $\begin{array}{c}\text { R } \\
\text { Specify-ing } \\
\text { Coeffici-ent }\end{array}$ & $\begin{array}{c}\text { Counted } \\
\text { F }\end{array}$ & $\begin{array}{c}\text { Degree } \\
\text { Of } \\
\text { Freedom } \\
\text { of }\end{array}$ & $\begin{array}{c}\text { Sig F* } \\
\text { Statistica-l } \\
\text { Sigdifico-nce }\end{array}$ & Statement & B & $\begin{array}{c}\text { Standard } \\
\text { Error }\end{array}$ & $\begin{array}{c}\text { Counted } \\
\mathrm{T}\end{array}$ & $\begin{array}{c}\text { Sigt* } \\
\text { Statistic-al } \\
\text { Signifi-cance }\end{array}$ \\
\hline $\begin{array}{l}\text { Social } \\
\text { Respons-ibility }\end{array}$ & 0.692 & 0.479 & $\begin{array}{c}189.08 \\
7\end{array}$ & 1 & $\begin{array}{c}0.00 \\
0\end{array}$ & $\begin{array}{l}\text { Continuous } \\
\text { Improvement }\end{array}$ & $\begin{array}{c}0.58 \\
5\end{array}$ & 0.043 & $\begin{array}{c}13.75 \\
1\end{array}$ & $\begin{array}{c}0.00 \\
0\end{array}$ \\
\hline
\end{tabular}

Impact will be with Statistical at the Significance at the level $(\mathrm{P} \geq 0.05)$.

Results of Table (7) indicates that the value ( $\mathrm{r}=0.692)$, this means that there is a positive relationship between the (continuous improvement) and (the social responsibility). And it is clear that the value of specifying coefficient $(r=0.479)$ this means that (the continuous improvement) had explained the sum of (\%47.9) from variation in the (social responsibility), with remaining the other factors stable. It is also clear that the F value had amounted (189.087) at the level of trust ( $\mathrm{Sig}=0.000)$ and this assures the moral coefficient at the level $(\mathrm{P} \geq 0.05)$.

And due to what preceded, we reject the fourth subsidiary nihilist hypothesis and accept the replacing subsidiary hypothesis that words: "there is an impact with statistical significance at the morale level $(\mathrm{P} \geq 0.05)$ for the continuous improvement in dimensions of the social responsibility". That is ascribed to the continuous improvement that is it from the most important value of the comprehensive quality management.

To specify any of the comprehensive quality management applications, it had the most prominent impact in adopting the social responsibility, then the stepwise (Multiple regressions) had been analyzed, and the results were as follows: 


\section{Macrothink}

Journal of Management Research

ISSN 1941-899X

2017, Vol. 9, No. 3

Table 8. Model summary and variation analysis to test the first main hypothesis

\begin{tabular}{|c|c|c|c|c|c|c|}
\hline \multirow{2}{*}{$\begin{array}{c}\text { The } \\
\text { Model }\end{array}$} & \multicolumn{3}{|c|}{ Model Summary } & \multicolumn{3}{|c|}{ ANOVA Analysis } \\
\hline & $\begin{array}{c}\mathrm{R} \\
\text { connection } \\
\text { Coefficient }\end{array}$ & $\begin{array}{c}\text { R } \\
\text { Specifying } \\
\text { Coefficient }\end{array}$ & Standard & $\begin{array}{c}\text { Degree of } \\
\text { Freedom } \\
\text { DF }\end{array}$ & $\begin{array}{c}\text { Counted } \\
\text { F }\end{array}$ & $\begin{array}{c}\text { Sig* } \\
\text { Level of } \\
\text { Significance }\end{array}$ \\
\hline 1 & 0.758 & 0.574 & 0.441 & 1 & 277.795 & 0.000 \\
\hline 2 & 0.803 & 0.644 & 0.404 & 2 & 185.623 & 0.000 \\
\hline 3 & 0.807 & 0.651 & 0.401 & 3 & 126.939 & 0.000 \\
\hline
\end{tabular}

At showing the table we find that the first model resulting from analyzing the stepwise Multiple Regression indicates that the variable of (concentrating clients) had explained the rate of (\%57.4) of the total variation occurring in (the social responsibility). The rate of explaining the total variation occurring in the (social responsibility) deduced (\%64.4), that is at adding (employees empowerment) to the (concentration on clients) in the second model. And at adding the variable of (the higher administration commitment) the rate of explanation raised to (\%65.1). Informing that different levels of $(F)$ in both models lies within the level of morale less than $(\mathrm{sig}=0.00)$ this assures the morale regression.

Table 9. Summary of results of regression coefficients of testing the first main hypothesis

\begin{tabular}{|c|c|c|c|c|}
\hline Model & Social Responsibility & B & $\begin{array}{l}\text { Counted } \\
\text { T value }\end{array}$ & $\begin{array}{c}\text { Sig*Level } \\
\text { Of Significance }\end{array}$ \\
\hline First & $\begin{array}{c}\text { Concentration on } \\
\text { Clients }\end{array}$ & 0.633 & 16.667 & 0.000 \\
\hline \multirow[t]{2}{*}{ Second } & Concentration on Clients & 0.414 & 8.448 & 0.000 \\
\hline & Employees Empowerment & 0.304 & 6.353 & 0.000 \\
\hline \multirow{3}{*}{ Third } & Concentration on Clients & 0.347 & 5.894 & 0.000 \\
\hline & Employees Empowerment & 0.263 & 5.107 & 0.000 \\
\hline & Higher Administration commitment & 0.134 & 2.012 & 0.045 \\
\hline
\end{tabular}


By showing result of the table we find that values of B in the three models at the different levels of $t$ lie at the level of significance $(\mathrm{sig}=0.045)$ or less and for all variables within models of stepwise regression and that came less than (0.05), and this assures the morale of regression coefficients, that indicates that impact of variables in the three variables is an impact with statistical significance. Also it was clear that impact of (continuous improvement) was un morale impact.

\section{The second main hypothesis}

1 Hol: "There are no differences with statistical significance at the morale level $(p \leq 0.05)$ in responses of the examinees in adopting the social responsibility ascribed to the demographic variables.

The first subsidiary hypothesis had been subdued to the Independent Sample t-test, mean while the rest of subsidiary hypotheses had been subdue to the one way ANOVA test. The results had been as follows:

2- Hol: "There are no difference with Statistical significance at the moral level $(\mathrm{P} \geq 0.05)$ in responses of the examinees in adopting the social responsibility ascribed to the social type".

Table 10. Testing the differences in adopting the social responsibility ascribed to the social type

\begin{tabular}{|c|c|c|c|c|c|}
\hline Social Type & $\begin{array}{c}\text { Arithmetic } \\
\text { Mean }\end{array}$ & $\begin{array}{c}\text { Standard } \\
\text { Deviation }\end{array}$ & $\begin{array}{c}\text { Value } \\
\text { Difference }\end{array}$ & T Value & Sig \\
\hline Male & 3.6121 & 0.6923 & \multirow{2}{*}{0.1688} & 1.817 & 0.071 \\
\cline { 1 - 3 } Female & 3.4433 & 0.6474 & & \\
\hline
\end{tabular}

The impact is with statistical significance at the level $(\mathrm{p} \leq 0.05)$

The table (10) indicates that the difference between both responses of males and females about adopting the social responsibility had amounted (0.1688) for the interest of the males, it is a non statistical significant, where the value of the counted $t$ was $(t=1.817)$ and the level of significance ( $\mathrm{Sig}=0.071$ ) it is bigger than 0.05 , so it can be said non-existence of morale differences in adopting the social responsibility ascribed to the social type.

So we accept the first subsidiary hypothesis, that Words:

"There are no differences with statistical significance at the morale level $(p \leq 0.05)$ in responses of the examinees in adopting the social responsibility ascribed to the social type."

2-2 Ho: " There are no differences with statistical significance at the morale level $(p \leq 0.05)$ in responses of examinees in adopting the social responsibility ascribed age. 
Table 11. Testing the differences in adopting the social responsibility ascribed to the variable of age.

\begin{tabular}{|l|l|c|c|c|c|c|}
\hline \multicolumn{1}{|c|}{ The Age } & $\begin{array}{c}\text { Sourced } \\
\text { of } \\
\text { Variation }\end{array}$ & $\begin{array}{c}\text { Squares } \\
\text { Total } \\
\text { SS }\end{array}$ & $\begin{array}{c}\text { Degrees } \\
\text { of DF } \\
\text { Freedom }\end{array}$ & $\begin{array}{c}\text { Average of } \\
\text { the } \\
\text { Squares } \\
\text { Total MS }\end{array}$ & $\begin{array}{c}\text { Value of } \\
\text { Counted } \\
\text { F }\end{array}$ & Sig \\
\hline The Social & $\begin{array}{l}\text { Between } \\
\text { Groups }\end{array}$ & 2.411 & 3 & 0.804 & & \\
& $\begin{array}{l}\text { Inside } \\
\text { Groups }\end{array}$ & 93.954 & 207 & 0.449 & 1.791 & 0.150 \\
& Total & 204 & & & \\
\hline
\end{tabular}

The table (11) clears non- existence of morale differences in responses of the sample individuals about adopting the social responsibility ascribed to the variable of age, for the value of (F) the counted was cleared and at (3) degrees of non- statistically significant freedom at the level of significance $(\mathrm{p} \leq 0.05)$ with a value amounting (1.791) and a level of significance ( $\operatorname{sig}=0.150)$ and it is bigger than (0.05), and so we accept the second subsidiary hypothesis that words "There are no differences with statistical significance at the morale level $(p \leq 0.05)$ in responses of the examinees in adopting the social responsibility ascribed to the age".

3-2 Ho: $:$ "There are no differences with statistical significance at the level of significance $(p \leq 0.05)$ in the responses of the examinees in adopting the social responsibility ascribed to the scientific qualification".

Table 12. Testing the differences in adopting the social responsibility ascribed to the variable of the scientific qualification

\begin{tabular}{|c|c|c|c|c|c|c|}
\hline $\begin{array}{c}\text { Scientific } \\
\text { qualification }\end{array}$ & $\begin{array}{c}\text { Source of } \\
\text { Variation }\end{array}$ & $\begin{array}{c}\text { Squares } \\
\text { Total } \\
\text { SS }\end{array}$ & $\begin{array}{c}\text { Degrees of } \\
\text { Freedom } \\
\text { DF }\end{array}$ & $\begin{array}{c}\text { Average of } \\
\text { Squares } \\
\text { Total MS }\end{array}$ & $\begin{array}{c}\text { Counted } \\
\text { F } \\
\text { Value }\end{array}$ & Sig \\
\hline Social & $\begin{array}{c}\text { Between } \\
\text { Groups }\end{array}$ & 2.032 & 3 & 0.677 & & \\
& Inside Groups & 91.922 & 204 & 0.451 & 1.503 & 0.215 \\
& Total & 93.954 & 207 & & & \\
\hline
\end{tabular}

Table 12 clears non- existence of morale differences in the responses of the sample individuals about the social responsibility ascribed to the variable of the scientific qualification, for the counted F value and at (3) degrees of non- statistical significance of freedom at the level of significance $(\mathrm{p} \leq 0.05)$ at a value amounting to $(1.503)$ and at significance level ( $\operatorname{sig}=0.215)$ and it is bigger than (0.05), so we accept the third subsidiary hypothesis that words: 
"There are no differences with statistical significance at the morale level $(p \leq 0.05)$ in responses of the examinees in adopting the social responsibility ascribed to the occupational nomination".

Table 13. Testing the differences in adopting the social responsibility ascribed to the variable of occupational nomination

\begin{tabular}{|c|c|c|c|c|c|c|}
\hline $\begin{array}{c}\text { Occupational } \\
\text { Nomination }\end{array}$ & $\begin{array}{c}\text { Variation } \\
\text { Source }\end{array}$ & $\begin{array}{c}\text { Squares } \\
\text { Total s }\end{array}$ & $\begin{array}{c}\text { Degrees } \\
\text { of } \\
\text { Freedom } \\
\text { DF }\end{array}$ & $\begin{array}{c}\text { Average of } \\
\text { Squares } \\
\text { Total MS }\end{array}$ & $\begin{array}{c}\text { Counted } \\
\text { F } \\
\text { Value }\end{array}$ & Sig \\
\hline The Social & $\begin{array}{c}\text { Between } \\
\text { Groups }\end{array}$ & 5.949 & 3 & 1.983 & & \\
\cline { 2 - 5 } Responsibility & Inside Groups & 88.005 & 204 & 0.431 & 4.597 & 0.004 \\
\hline
\end{tabular}

The Table (13) clears the existence of morale differences in responses of the sample individuals about adopting the social responsibility ascribed to the variable of the occupational level, where the value of $\mathrm{F}$, the counted is cleared and at (3) non- statistical significant freedom degrees at the level of significance $(\mathrm{p} \leq 0.05)$ at a value amounted to $(4.597)$ and a level of significance ( $\mathrm{Sig}=0.004)$ and it is less than $(0.05)$, so we reject the fourth subsidiary hypothesis.

We accept the replacement that words: "There are differences with statistical significance at the morale level $(\mathrm{P} \geq 0.05)$ in the responses of the examinees in adopting the social responsibility ascribed to the occupational nomination".

That is ascribed to the how we graduate in the serial occupation ascending that increased Knowledge and experience to understand the environmental variables surrounding the hospital, also increased awareness of policies, that serve the interest of the hospital and increases its profits on the long run, in addition to the authorities granted to chair persons of departments that enable them of taking important decisions at work.

To specify sources of difference, (Scheffe) test for dimensional comparisons had been applied, and the results were as follows: 
Table 14. Results of (Scheffe) for the dimensional comparisons between the arithmetic means to pin-point the differences in adopting the social responsibility ascribed to the variable of occupational nomination.

\begin{tabular}{|l|c|c|c|c|c|}
\hline \multicolumn{1}{|c|}{ Class } & Average & $\frac{\text { Director }}{\mathbf{3 . 7 9 9 2}}$ & $\frac{\text { Dir.Deputy }}{\mathbf{3 . 6 1 4 6}}$ & $\frac{\text { Chair }}{\frac{\mathbf{3 . 7 0 7 8}}{\mathbf{3 e r s o n}}}$ & $\frac{\text { Supervisor }}{\mathbf{3 . 3 7 5 4}}$ \\
\hline Director & 3.7992 & & & & \\
\hline $\begin{array}{l}\text { Director } \\
\text { Deputy }\end{array}$ & 3.6146 & 0.1846 & & & \\
\hline Chairperson & 3.7079 & $0 . .0914$ & 0.0932 & & \\
\hline Supervisor & 3.3754 & 0.4238 & 0.4238 & 0.2392 & $0.3324^{*}$ \\
\hline
\end{tabular}

*Significant at the level of significance $(\mathrm{P} \geq 0.05)$

The table (14) shows that there is a difference with statistical significance in responses of the sample individuals about adopting the social responsibility ascribed to the variable of occupational nomination between the classes of

(Chairperson) and the class of (Supervisor), where the value of difference was $(0.3324)$ for the interest of the class of (chair person).

\section{The third main hypothesis}

3-Ho: There are no differences with statistical significance at the morale level $(\mathrm{P}>0.05)$, between Jordanian private and Public hospitals in adopting the social responsibility.

The third main hypothesis had been subdued to the Independent Sample t-test, and the results were as follows:

Table 15. Test of differences in adopting the social responsibility ascribed to the variable of the variable of the hospital sector".

\begin{tabular}{|c|c|c|c|c|c|}
\hline $\begin{array}{c}\text { Hospital } \\
\text { Sector }\end{array}$ & $\begin{array}{c}\text { Arithmetic } \\
\text { Mean }\end{array}$ & $\begin{array}{c}\text { Standard } \\
\text { Deviation }\end{array}$ & $\begin{array}{c}\text { Difference } \\
\text { Value }\end{array}$ & t Value & Sig \\
\hline Public & 3.2780 & 0.5343 & 0.5280 & 6.120 & 0.000 \\
Private & 3.8061 & 0.7063 & & \\
\hline
\end{tabular}

*The impact is with statistical Significance at the level $(\mathrm{P} \geq 0.05)$

The Table(15) indicates that the difference between both averages of responses of employees in public and private hospitals about adopting the social responsibility had amounted to (0.5280) for the interest of the private hospitals, it is a difference statistically significant, where the absolute value of counted $|t|$ is $6.120 \mid=t$ bigger than the table class (1.96) and at a moral level ( $\mathrm{Sig}=0.000)$ and it is less than $(0.05)$, and so it can be said with existence of morale differences in adopting the social responsibility between the public and private hospitals for the interest of the private.

And so we reject the third main hypothesis, and we accept the replacing that words: 
"Differences with statistical significance exist at the morale level ( $\mathrm{P} \geq 0.05)$, between the private and public hospitals in adopting the social responsibility".

\section{Results and Recommendations}

Results

Depending on analyzing data of study, and testing hypotheses the following results were deduced:

1. Trends of individuals of the sample showed that the general level of the comprehensive quality management applications in the private and public hospitals was with medium significance. It was also pin-pointed that the variable (concentration on clients) had occupied the first rank, followed by the variable (of the higher Administration commitment), then the variable of (the continuous improvement), mean while the variable (employees empowerment) occupied the last rank. Also the relative significance of the comprehensive quality management applications, at a medium level, except the variable (concentration on clients), which was with the relative significance high.

2. Answers of the sample individuals showed that the level of adopting the social responsibility at public and private hospitals. was with medium relative significance. Also cleared that (the legal dimension) had occupied the first rank, followed by (the ethical dimension), then the (economic dimension), meanwhile the (human dimension) ((Voluntary)) occupied the last rank, and the significance of both the legal and the ethical dimensions were high, meanwhile it was medium at both dimensions the economic and the human (Voluntary).

3. Results of the first main hypothesis test showed existence of morale impact for application of the comprehensive quality management on the level of adopting the social responsibility at public and private hospitals, that is at studying the impact of the comprehensive quality management applications altogether, and the morale impact had appeared at each of (concentration on clients and employees empowerment), meanwhile the morale impact at both variables (the higher administration, and the continuous improvement ) did not appear, this assures the significance of the comprehension quality management in adopting practices of the social responsibility .

Results of testing the hypotheses branching from the first main hypothesis showed existence of the morale impact for all applications of the

4. comprehensive quality management on adopting the social responsibility, at the Jordanian public and private hospitals, that is at studying the impact of every variable at a single form, this assures the significance of all applications of the comprehensive quality management . Also clears by depending on the previous result that the impact of the comprehensive quality management on adopting the social responsibility is not equal, where the impact of each of (the 
higher administration commitment and the continuous improvement) at studying the applications altogether.

5. Results of analyzing the stepwise regression showed that the variable of (concentration on clients) had the most prominent impact in adopting the social responsibility at private and public hospitals, followed from part of impact significance the variable of (employees empowerment), then (the higher administration commitment), meanwhile the stepwise regression analysis did not show the existence the moral impact of the variable (the continuous improvement).

6. Results of testing the hypotheses branching from the second main hypothesis showed non- existence of morale differences in trends of the sample individuals about adopting the social responsibility at private and public hospitals, except for the variable of (the occupational level), where it was clear the existence morale difference between trends of chairpersons and supervisors, for the interest of chairpersons.

7. The third main hypothesis result showed the existence of morale differences in adopting the social responsibility, between public and private hospitals, that is for the interest of private hospital.

\section{Recommendations}

Depending on what had been deduced of results, both researchers recommend the following:

1. Administration of public and private hospitals have to depend the policy of participating the employees in the administrating decisions-making, and to appreciate this participation from the responsible, that is to increase the level of employees empowerment through concluding periodical meetings to

1. Discuss the new developments of work, changes in the surrounding environment, and giving them more authorities, and working to motivate them substantially and morally through rewards and promotions.

2. Concern about development of employees abilities to solve problems, introducing appropriate solutions and inventing what is new, through concluding sessions of brain-storming. This matter requires saving training programs in domains of improving work and delegating employees to external training courses to be informed of successful experiments and getting benefit of them, of what concerns the nature of work to increase their experiences and abilities to solve problems that may face them at work.

3. Increasing the public and private hospitals of adopting the social responsibility, and increasing concentration on the human (Voluntary) dimension, through concern about offering studying scholarships saving work opportunities for people of special needs, and commitment with voluntary initiatives. This requires higher administration aware of this trend significance 
through saving everything substantially necessary and lay financial specifications in the budget of the hospital enlisted under the nomination of the social responsibility and concluding workshops for employees to define the significance of this trend to the organization and the community.

4. Necessity of reflecting the practices of the social responsibility at the public and private hospitals on employees, especially what relates with laying an appropriate ladder of wages, for results showed that it occupied the lowest averages.

5. 5. Sharing of public and private hospitals in health development for the individuals of the local community by offering voluntary health days and organizing educational symposiums to define contagious diseases and methods of prevention and also by offering the financial support to the projects, that concern about improving the infrastructure to prevent environmental pollution, that may cause dangerous diseases can catch the community, and necessity of hospitals concern with correct getting rid of the harmful medical remains and taking the best ways to prevent their harmful impact against the community individuals health.

\section{References}

Al- DaradKeh, Ma'moon, \& Ash-Labi, Tareq. (2002). Quality in modern organizations, Jordan, Amman: Dar Safa' for Publication and Distribution.

Al-Ghalibi, Taher Muhsen Mansour, \& Al-A'miri Saleh Mahdi Muhsen. (2010). The Social Responsibility and Business Ethics (Business \& Community) (3rd.ed.) Jordan, Amman: Dar Wael for Publication.

Al-Ghalibi, Taher Muhsen Mnsour, \& Al-Amiri, Saleh Mahdi Muhsen. (2005). The Social Responsibility and Business Ethics (Business \& Community). Jordan, Amman: Dar Wael for Publication.

Al-Kababji, Majdi Wael, \& Abu A'wwad, Bala'. (2014). Measuring the Impact of Using the System of the Financial Performance in the Public Sharing Industrial Companies. (32), Journal of Jerusalem Open University for Studies, Jerusalem, Palestine.

Al-Kbeisi, Luluwa Mohammad. (2011). Impact of Applying the Comprehensive Quality Management in Kinder-Gartens in the State of Qatar. Unpublished Master Degree Dissertation, The open Arab British University.

Al-Khaldi. I brahim, Ali Obaid. (2015). Impact of the commitment of hospitals with the Social Responsibility in quality of concept health services: an applied study on a sample of patients at private hospitals in Amman City. Jordan. A Master Degree Dissertation / unpublished, Zarqa University, Zarqa, Jordan.

Al-Khalidi, Ibrahim Bader Shihab. (2010). Ethical and social responsibility for the contemporary business organization. Jordan, Amman: Dar El- I'lam for Publication and Distribution. 
Al-Omari, Jameela, \& Mohammad Zargoon. (2009). Role of the External Parties of the Social Responsibility in Achieving the Competitive Trait (A Case Study of Insurance Companies in Wargella State). Journal of Algerian Associations Performance, 8. Wargella University, Algiers, Al-gieria.

Al-Qaryoti, Mousa Gasem, Al-Khawaldeh, Riyad Abdullah, Gteishat, Maher Kamal, Al-Hfiedi, Mohammad Faleh, Al-Ma'yta, \& Mohammad A'twa. (2014). Role of Responsibility in Achieving the Competitive Trait: A Case Study in Zein Company for Mobile Communications. Dirasat "Administrative Science", 41, University of Jordan, Amman, Jordan.

Al-Zu'bi, Hasan. (2015). Extent of the concern of Private Jordan hospitals administration with applying requirements of the comprehensive quality management and their reflection in information quality at it. University of Applied Science, Amman, Jordan. https IIwww researchgate.net

An-Nashmi, Morad Mohammad, \& Gaid, I'mad Abdel Wahhab. (2015). Relationship between the Social Responsibility and the Mental Images of Organizations (A Case Study about the Science and Technology University in Yemen). Journal of Social Studies, 45, University of Science and Technology, Sana, Yemen.

An-Neimi, Faten Amin. (2015). The Social Responsibility and its Impact on the Cost Market. Unpublished Master Degree Dissertation, Zarqa University, Zarqa, Jordan.

Ash-Shiyyab, Ahmad Mohammad, \& Abu Hammour, A'nan Mohammad. (2011). Contemporary Administrative Concepts, Jordan, Amman: Academicians for Publication and Distribution.

As-Samirrai', Mahdi. (2007). The Comprehensive quality in Both Sectors Productive and Serviceable. Jordan, Amman: Dar Jareer for Publication and Distribution.

As-Sayrafi, Mohammad Abdel Fattah. (2003). Pioneer Administration. Jordan, Amman: Dar Safa' for Publication and Distribution.

As-Soodani, Areej Dawood Salman. (2014). Impact of Innovation of Supply Series in Practices of the Comprehensive Quality: An Applied Study in the Iraqi Industrial Companies Acting in Jordan. Unpublished Master Degree Dissertation, Middle East University Amman, Jordan.

At-Tai', Ra'd Abullah, \& Gadadh, I'isa. (2008). The Comprehensive Quality Management. Jordan, Amman: Darel Yazoori Al-I'lmeyyeh for Publication and Distribution.

At-Tamimi, Fawwaz, \& Al-Khateeb, Ahmad (2008). The comprehensive quality management and requirements of qualification for Iso (9001). Jordan, Amman: Modern World of Books.

Az-Zu'bi, Ali Falah. (2009). Marketing management Jordan, Amman: Darel Yazoori for Printing and Publication.

Bin Jeimah, Mariam, \& Bin Jeimah, Naseral (2011). The social responsibility and ethics of management. The Third International Meeting entitled Business Organizations and the Social Responsibility. Bashar University, Algiers, Algeria. 


\section{Macrothink}

Journal of Management Research

ISSN 1941-899X 2017, Vol. 9, No. 3

Bookmeish, La'li, \& Hoteih, Omar. (2014). Role of quality of University Education in motivating the social service in the Arab Homeland. The Arab International Conference to Guarantee the Quality of Higher Education. Zarqa University.

Hmoud, Khdeir Kamel. (2009). Comprehensive quality management (4th.ed.). Jordan, Ammani Darel Al-Maseera for Publication and Distribution.

Ibn Manthour, Mohammad Bin Makram Bin Ali. (1889). Lisanul Arab, Dar Sader, Beirut, Lebanon.

Jaradat, Naser, \& Abdul Hamam, A'zzam (2014). The Ethical and Social Responsibility of Organizations. Jordan, Amman: Ithra' for Publication and Distribution.

Jawdat, Mahfouz Ahmad. (2009). The comprehensive quality management: concepts and. 4th.ed. Amman. Jordan: Dar Wael for Publication and Distribution.

Jawdat, Mahfouz Ahmad. (2014). The comprehensive quality management: concepts and applications. (7th.ed.). Amman, Jordan: Dar Wael for Publication and Distribution.

Naji, A'mila Muhsen Ahmad. (2011). The Iraqi Consumer Awareness of the Social Responsibility of Companies. Journal of Baghdad College for Economic Science, 28, Baghdad University, Baghdad, Iraq.

Olwan, Qasem Nayef. (2016). The Comprehensive Quality Management and Iazo Requirements 2000: 9001, (4th.ed). Jordan, Amman: Dar Ath-Thagafa for Publication and Distribution.

Society of the Arab Assembly for legal auditors. (2001). The social responsibility and ethics of management. Amman, Jordan.

The Holy Qura'n.

The Prophetic Sunnah. 